\title{
PEANUT
}

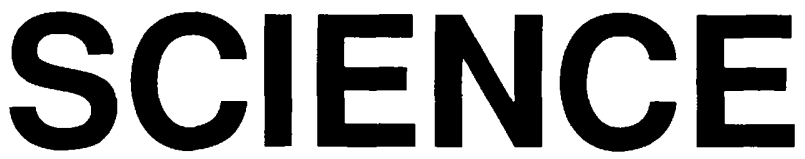

\section{Effect of Temperature on Urediniospore Production and Germinability in Puccinia arachidis $^{1}$}

P.V. Subba Rao ${ }^{2}$, P. Subrahmanyam ${ }^{3 *}$, and D. McDonald ${ }^{4}$

\begin{abstract}
Elficet of temperature on urediniospore production in Puccinia arachidis was investigated under monocyclic infection using detuched leaves of the susceptible peanut (Arachis hypogac!n L.) cultivar TMV 2. Urediniospores produced at differcul temperatures were also examined for their germinability in vitro. The optimal temperature for urediniospore production was at abuut 20 and $25 \mathrm{C}$. Temperatures below $20 \mathrm{C}$ or above 30 $C$ were highly detrimental to urediniospore production. There were also marked differences in the percent germination of urediniospores produced at different temperatures. Urediniospores produced at 20 and $25 \mathrm{C}$ showed the highest germination percentages. The interaction of temperature with urediniospore production and germinability is important in understanding the development of peanut rust epidemics.
\end{abstract}

Kiy Words: Peanut, groundnut, Arachis hypogaea, rust, Puccinin arachidis, epidemiology.

Rust, caused by Puccinia arachidis Speg., is an important foliar disease of peanut (Arachis hypogaea L.) in all major peanut-producing areas of the world (6). Climatic factors such as rainfall, temperature, and relative humidity have been reported to be important in the development of peanut rust epidemics (3). Availability of water on the leaf surfaces for over $6 \mathrm{hr}$ and temperatures of 20-25 $\mathrm{C}$ are necessary for urediniospore germination and infection $(6,9)$. Rust development is most rapid when temperatures are around $25 \mathrm{C}$. hut decreases at lower or higher tempera-

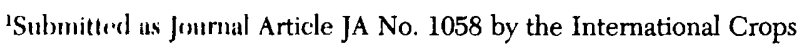
Research Instifufe for the Semi-Arid Tropics (ICRISAT).

${ }^{2}$ Post Doctorul fiollow. Dept. of Biology, Univ. College London, Gower Street. I sondon WV :Ifi, 6 B BT, UK.

${ }^{3}$ Principul Scrintist (Pathology), SADC/TCRISAT Groundnut Project, Chitedza Agric. Mr's. Stu., P'.O. Box 1096, Lilongwe, Malawi.

${ }^{4}$ Dircetor (C,rop l'rotretion Division), ICRISAT Asia Center, Patancheru, Andhra Praulesh 502 :324, India.

*Corresponding inullor. tures. Although the sporulation index was found to be highest at temperatures of 20-25 C (Subrahmanyam, unpubl. data), the optimum temperature for urediniospore production was not determined. In addition, information on the germinability of urediniospores produced at various temperatures would be useful in understanding the epidemiology of peanut rust.

This paper reports investigations on the effects of temperature on urediniospore production by $P$. arachidis and the germinability of urediniospores produced at different temperatures.

\section{Materials and Methods}

Plant Material. Potted plants of the rust-susceptible peanut cultivar TMV 2, were raised in a glasshouse as described by Subrahmanyam $e t$ al. (7). At $40 \mathrm{~d}$ after sowing, the middle leaf on the main stem of each plant was excised through the pulvinus and leaves were arranged in plastic trays $(56 \times 25 \times 5 \mathrm{~cm})$ with their petioles buried in steam-sterilized river sand moistened with Hoagland's nutrient solution. There were four replications arranged in randomized blocks. Each replicate treatment consisted of two leaves. The trays were covered with a thin plastic sheet and incubated for $24 \mathrm{hr}$ in a plant growth chamber (Percival Refrigeration and Mfg. Co., Boone, IA 50036) at $25 \mathrm{C}$ with $12 \mathrm{hr}$ photoperiod (5000 lux).

Inoculation. Urediniospore inoculum was produced on detached leaves of TMV 2 in a plant growth chamber. Urediniospores were harvested using a cyclone spore collector (ERI Instrument Shop, Iowa State University, Ames, IA 50011) and suspended in sterile distilled water containing traces $(10 \mathrm{drops} / 1000 \mathrm{~mL}$ ) of Tween 80 (polyoxyethylene sorbitan mono-oleate). The suspension was adjusted to a concentration of approximately 50,000 spores $/ \mathrm{mL}$ using a hemocytometer. Leaves were inoculated with the urediniospore suspension sprayed on with a plastic atomizer. Leaves were then incubated in a plant growth chamber at $25 \mathrm{C}$ with a $12 \mathrm{hr}$ - photoperiod (5000 lux).

At $14 \mathrm{~d}$ after inoculation, when there was $100 \%$ rupturing of uredinia, the number of uredinia per leaf was counted. Urediniospores were collected using a cyclone spore collector from each set of leaves and discarded. The leaves were then transferred to plant growth chambers for incubation at $10,15,20,25,30$ and $35 \mathrm{C}$.

Urediniospore Production. Urediniospores were collected using a cyclone spore collector into $5-\mathrm{mL}$ glass vials from each set of leaves incubated at various temperatures for 2, 4, 6, 8, 10, and $12 \mathrm{~d}$ after initial spore removal. Known volumes of distilled water containing Tween 80 
were added to the vials which were then shaken for 1 min on a vortex mixer. Using a hemocytometer, six separate aliquots from each vial were examined under the microscope to determine the number of urediniospores present. Urediniospore output per uredinium at various temperatures was calculated by dividing total numbers of urediniospores by the number of uredinia per leaf.

Urediniospore Germination. Portions of the urediniospore suspensions prepared at 4,8 , and $12 \mathrm{~d}$ after initial-spore removal were used to assess the germinability of urediniospores produced at each temperature. Urediniospore suspensions were streaked over the surface of $2 \%$ water agar in $9-\mathrm{cm}$-diameter glass petri dishes. Five petri dishes were prepared for each replicate treatment. The petri dishes were incubated in dark for $3 \mathrm{hr}$ at $25 \mathrm{C}$ and then exposed to formaldehyde vapor to prevent further germination and germtube growth. A total of 500 urediniospores (100 spores/petri dish) was examined for each treatment under a stereomicroscope $\left(\begin{array}{ll}x & 70)\end{array}\right)$ and the percentage germination was recorded.

The experiments were conducted three times on different dates. Analyses of variance (ANOVA) were performed initially for each experiment to examine the effects of various temperature levels on urediniospore production and their germinability. Further analysis was carried out on combined data from all experiments. Regression equations relating the temperature $x$ mean urediniospore production and temperature $\mathrm{x}$ mean germinability of urediniospores were constructed.

\section{Results and Discussion}

In the present study, the pathogen was allowed to establish in the host tissues until the maturity of uredinia by incubating the leaves at $25 \mathrm{C}$. The leaves were then transferred to various temperatures to investigate the effects of temperature on urediniospore production and germinability of urediniospores.

Effect of Temperature on Urediniospore Production. There was a highly significant $(\mathrm{P}=0.01)$ effect of temperature on urediniospore production. The mean number of urediniospores produced per uredinium increased with increase in temperature $\left(\mathrm{R}^{2}=0.92\right)$ from 10 to $20 \mathrm{C}$ and then decreased from 25 to $35 \mathrm{C}$ (Fig. 1). This agrees with the findings of Savary (3). Similar trends in the production of urediniospores have also been observed in various other rust pathogens such as $P$. hordei (8), $P$.

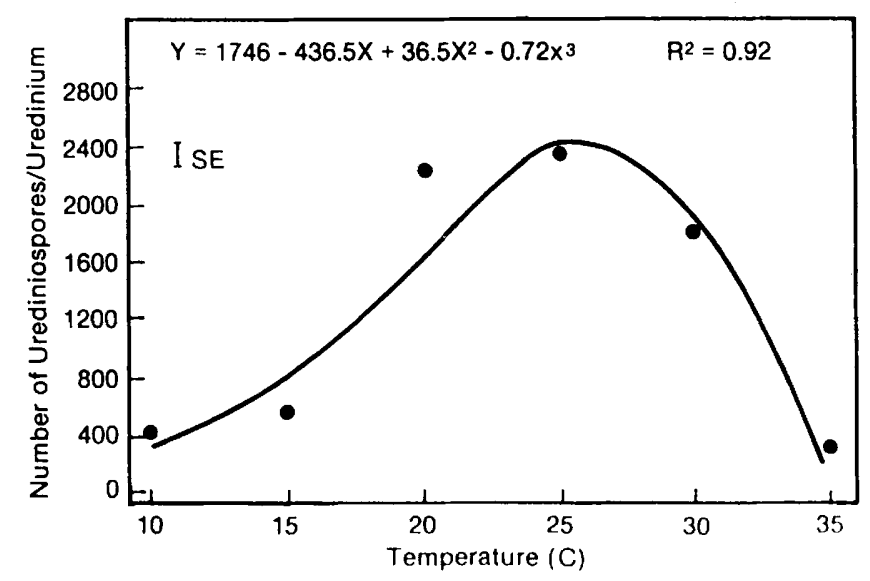

Fig. 1. Effect of tempenature on corediniospore production in Puccinia arachidis. Each value denotes a menn of sis tumple, $(2,4,6,8,10$, and 12 d after initial spore removal) collected al

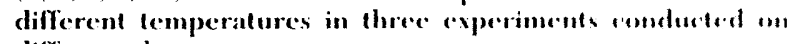
different dates. graminis l. sp. Iritici (2), and $P$. recondita (1). Highest numbers of urediniospores per uredinium were produced at $25 \mathrm{C}$ between 2 and $6 \mathrm{~d}$ after initial spore removal and at $20 \mathrm{C}$ between $s$ and 12 d after initial spore removal. In general, temperatures 20 and $25 \mathrm{C}$ were most optimal for urediniospore production. Urediniospore production was very low ( $<600 \mathrm{spore}$ / $/$ uredinium) on all sampling days at 10, 15 and $35 \mathrm{C}$ (Fig. 1).

Germinability of Urediniospores. There was a highly significant $\left(P=0.01, R^{2}=0.94\right)$ effect of temperature on the germinability of urediniospores. Urediniospores produced at 20 and $25 \mathrm{C}$ showed the highest germination percentages on water agar at all times of sampling (Fig. 2). Temperatures below $20 \mathrm{C}$ or above $25 \mathrm{C}$ were less conducive to spore germinability. Urediniospores produced at $35 \mathrm{C}$ had the lowest percentage germination of all times of sampling (Fig. 2)

Urediniospore production and germinability were very

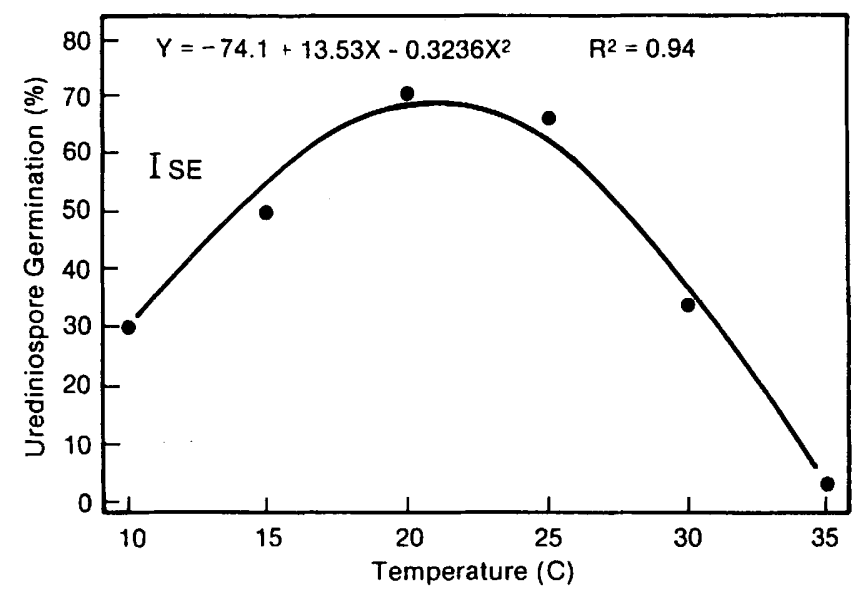

Fig. 2. Germinability of urediniospores of Puccinia arachidis produced at different temperatures. Each value denotes a mean of threc samples $(4,8$, and $12 \mathrm{~d}$ after initial spore removal) collected at different temperatures in three experiments conducled on different dates.

low at higher and lower tomperatures. Low sporulation index $(1=$ no spore production and $5=$ extensive spore production) of P. arachidis at 15 and $30 \mathrm{C}$ was also observed during investigations on the effects of temperature on

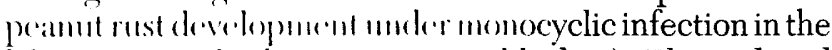
laboratory (Subrahmimuam, :mpubl. data). The reduced uredinicspore production at lomperatures above and below

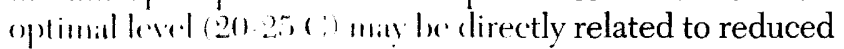
gum olsomed in the vialilits of urediniospores produced at

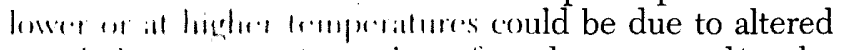

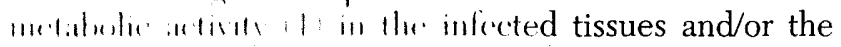

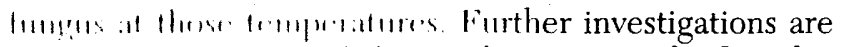

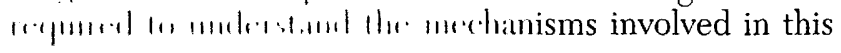

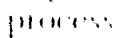

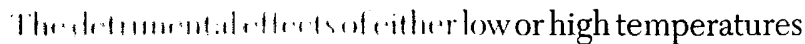

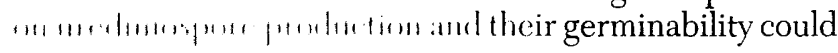


have an important bearing on the development of peanut rust epidemics in areas where the atmospheric temperatures are either below $20 \mathrm{C}$ or above $30 \mathrm{C}$ for prolonged periods. In Hyderabad, located in peninsular India, rust development is slow and less severe on peanut crops grown during the dry, postrainy (Dec. to May) seasons (5). Although day temperatures are optimum (mean $28 \mathrm{C}$ ) for rust development during the early part of the season (Dec. to Feb.), night temperatures are low (mean $13 \mathrm{C}$ ). In the later part of the season (April-May), day temperatures are high (mean $38 \mathrm{C}$ ) and the night temperatures are optimal (mean $25 \mathrm{C})$ for rust development. These fluctuations in temperature could be important in explaining the reduction of rust development and severity in the postrainy season peanut crops. Further studies are necessary to relate the temperature duration during the day or night on spore production and germinability.

Subrahmanyam et al. (7) reported that even under optimal temperatures the production of urediniospores was very low and urediniospore viability was poor in rust-resistant peanut genotypes. Further research is necessary to determine the genotype and temperature interaction on urediniospore production and germinability. Such information would be useful in understanding the host-pathogen-environment interaction in peanut rust epidemic:s.

\section{Literature Cited}

1. Eyal, Z., and J.L. Peterson. 1969. Uredospore production of five races of Puccinia recondita Rob. ex Desm. as affected by light and temperature. Can. J. Bot. 45:537-540.

2. Katsuya, K., and G.J. Green. 1967. Reproduction potentials of races 15 and 56 wheat stem rust. Can. J. Bot. 45:1077-1091.

3. Savary, S. 1985. Effets du niveau de contamination et de la temperature sur quelques e'tapes du developpement de Puccinia arachidis Speg. Agronomie 5:479-485.

4. Staples, R.C. 1965 . Acid phosphatases from healthy and rust infected Pinto bean leaves. II. Effects of removing apical meristem. Contrib. Boyce Thompson Inst. 23:83-92.

5. Subrahmanyam, P., and D. McDonald. 1980. Groundnut rust-Its survival and carry-over in India. Proc. Ind. Acad. Sci. 91:93-100.

6. Subrahmanyam, P., and D. McDonald. 1987. Groundnut rust disease Epidemiology and control. pp. 27-39. In Proc. Discussion Group Meeting on Groundnut Rust Disease, Sept. 1984. ICRISAT Center, Patancheru P.O., India.

7. Subrahmanyam, P., D. McDonald, and P.V. Subba Rao. 1983. Influence of host genotype on uredospore production and germinability in Puccinia arachidis. Phytopathology 73:726-729.

8. Teng, P.S., and R.C. Close. 1978. Effect of temperature and uredinium density on urediniospore production, latent period, and infectious period of Puccinia hordei Otth. New Zeal. J. Agric. Res. 21:287-96.

9. Zhou, L. 1987. The groundnut rust situation in the People's Republic of China. pp. 103-106. In Proc. Discussion Group Meeting on Groundnut Rust Disease, Sept. 1984. ICRISAT Center, Patancheru P.O., India.

Accepted June 18, 1994 